\title{
CHAPTER SIX \\ Work and Education: The Case of Laboring Women Poets in England, Scotland, and Germany
}

SUSANNE KORD

During the age of Enlightenment, women stopped working. Or, to put it somewhat differently, during the age of Enlightenment, "women" stopped “working."

\section{“WORK”}

Into the strife

Of busy life

The man must rush, must work and toil,

And plant and build,

Must wake and watch,

And hoard and snatch,

And dare the peril for the spoil.

Wealth pours in its plenteous streams,

With wealth are bent the garner's beams; 
His house's widen'd rooms with wealth are fill'd;-

That house the home of comfort; there

The matron-mother plies her care,

Versed in every saving art;

Well she plays the housewife's part:

To the girls imparts her skill,

Keeps the boys from doing ill;

Directs with well discerning eye

The busy hand of industry;

With art to win, and care to keep,

Adding to the gather'd heap.

The sweet-scented drawers with treasures she fills,

She twirls the spun thread round the quick flying wheels,

Collects in the clean and well order'd chest

The smooth shining wool, the linen snow white,

And makes every thing there look polish'd and bright,

And is never at rest. ${ }^{1}$

In England, Scotland, and Germany, the countries under discussion here, the age of Enlightenment engendered major philosophical shifts in attitudes toward women's education and coincided with major economic shifts, among them the Industrial Revolution. ${ }^{2}$ The move from predominantly agricultural to predominantly industrial societies resulted in the dissociation of gainful employment from the domestic sphere. Particularly the educated middle class, which rose to new prominence during the Enlightenment, distinguished between work performed by the man outside of the house and housework performed by the woman inside. The new bourgeois understanding of work as segregated by both space and gender enabled a far greater hierarchization (the understanding of remunerated work performed by men/outside being more valuable than unremunerated work done by women/inside) than would have been practicable in times when men and women worked side by side in house, barn, and field and very often performed the same tasks. ${ }^{3}$ This new framework is not merely economic but also conceptual; it describes a changed view not only of work but also of women. Once middle-class women had been defined in philosophy and literature as "Beautiful Souls," as embodied in Friedrich Schiller's ethereal creatures who joyously and effortlessly fulfill their "feminine destiny," 4 it became impossible to see them as workers. Once the house had become identified with the private sphere, as the safe haven to which the middle-class man returns after a hard day at "work and toil," the very idea of 
work was banished from it. In the economic realm, this meant the eradication of women's gainful employment; in fact, the bourgeois male's ability to keep his wife at home (not "working") became one of the surest indicators of his economic success. ${ }^{5}$ Conceptually, the understanding of the house as a "home" necessitated the redefinition of women's (house)work as something other than work. Although the prompt and flawless performance of housework became one of the most defining aspects of the perfect middle-class housewife, she was expected, to employ a phrase from the poem by Schiller quoted earlier, to "ply

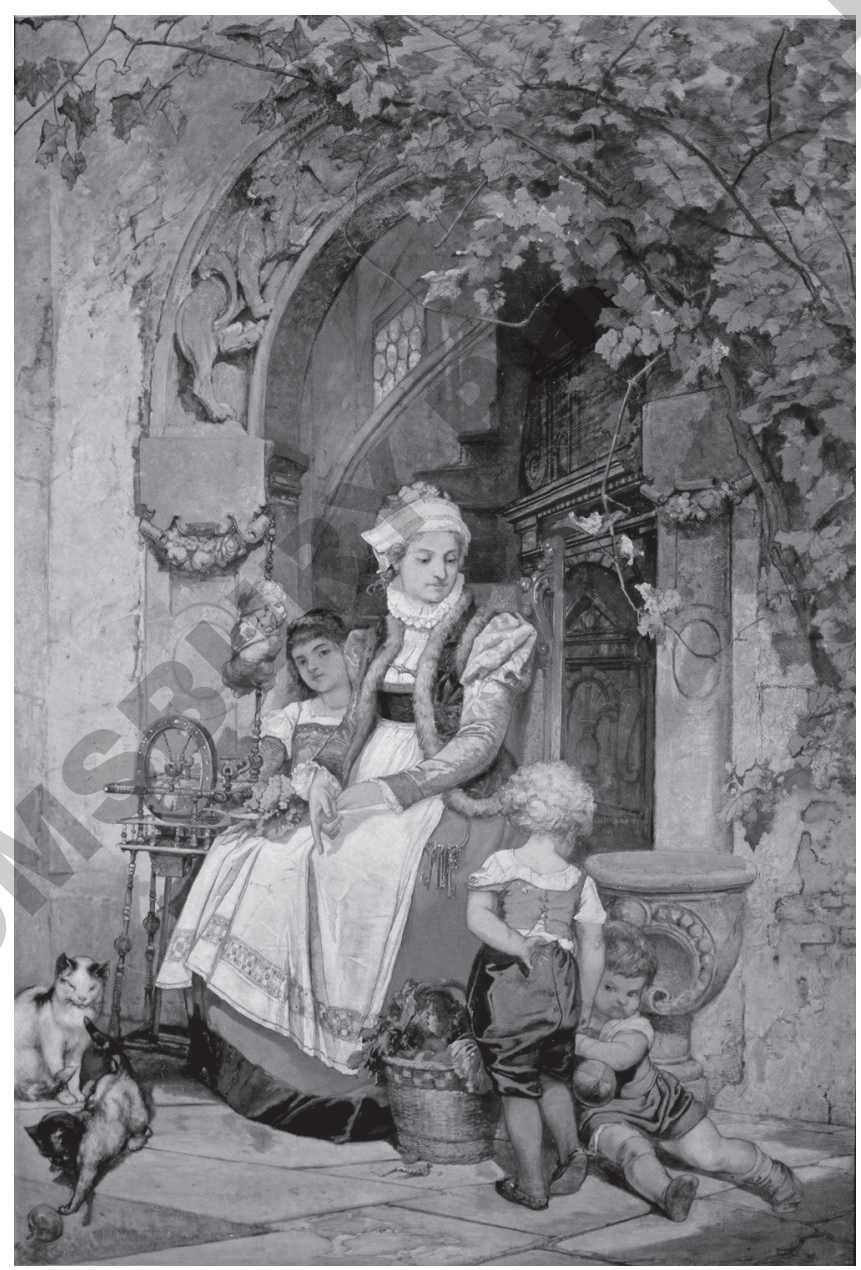

FIGURE 6.1: Ernst Erwin Oehme, illustration to Friedrich Schiller's "Das Lied von der Glocke" ("The Song of the Bell") (1872-77). Courtesy of Kurt Kramer, www.glocken-online.eu. 
her care," not work. Graceful, charming, gentle, and refined, the Beautiful Soul may be responsible for the success of the six-course dinner for forty, but she must not, under any circumstances, permit her efforts to appear as work-in front of the guests, she cannot even be seen to supervise the servants. ${ }^{6}$

The Enlightenment, in other words, marks the first stage of two fundamental conceptual shifts, one radically redefining ideas of work, the other radically redefining ideas of femininity. In the context of the Industrial Revolution, "work" becomes something performed outside of the house for money, associated with strife and contrasted with the peace reigning in the house. "Women" are viewed as innocuously gracious creatures whose function it is to turn the house into the home of comfort and thriftily preserve the wealth amassed by their men. Women soothe and care, they collect and preserve, they teach and direct. They make everything look polished and bright. What they do not do, under any circumstances, is work.

In the age of Enlightenment, women stopped "working."

\section{"WOMEN"}

Well, children, whar dat is so much racket der must be something out o' kilter. I tink dat 'twixt de niggers of de Souf and de women at de Norf all a talkin 'bout rights, de white men will be in a fix pretty soon. But what's all dis here talkin' 'bout? Dat man ober dar say dat women needs to be helped into carriages, and lifted ober ditches, and to have de best places_and ain't I a woman? Look at me! Look at my arm! . . . I have plowed and planted and gathered into barns, and no man could head me-and ain't I a woman? I could work as much as any man (when I could get it), and bear de lash as well—and ain't I a woman? I have borne five children and I seen 'em mos all sold off into slavery, and when I cried with a mother's grief, none but Jesus hear-and ain't I a woman? ${ }^{7}$

The answer to the rhetorical question posed by the abolitionist and former slave Sojourner Truth would evidently have to be a resounding "No." For although she was biologically a woman, she was not perceived as such by her contemporaries. She was perceived as a worker, more specifically-in this case-as a black and a slave.

Woman was a term that indicated not only whiteness but also middle-class status, a term that implied privileges as well as a (different) kind of oppression. Identity, a stable category for members of a dominant culture/class/gender and expressible in a single name (Goethe = Goethe; Shakespeare $=$ Shakespeare), 
FIGURE 6.2: Photographic image of Sojourner Truth on carte de visite with inscription, "I sell the shadow to support the substance, Sojourner Truth" (1864). Still image. Part of the Alfred Withal Stern Collection of Lincolniana. Library of Congress, Rare Book and Special Collections Division.

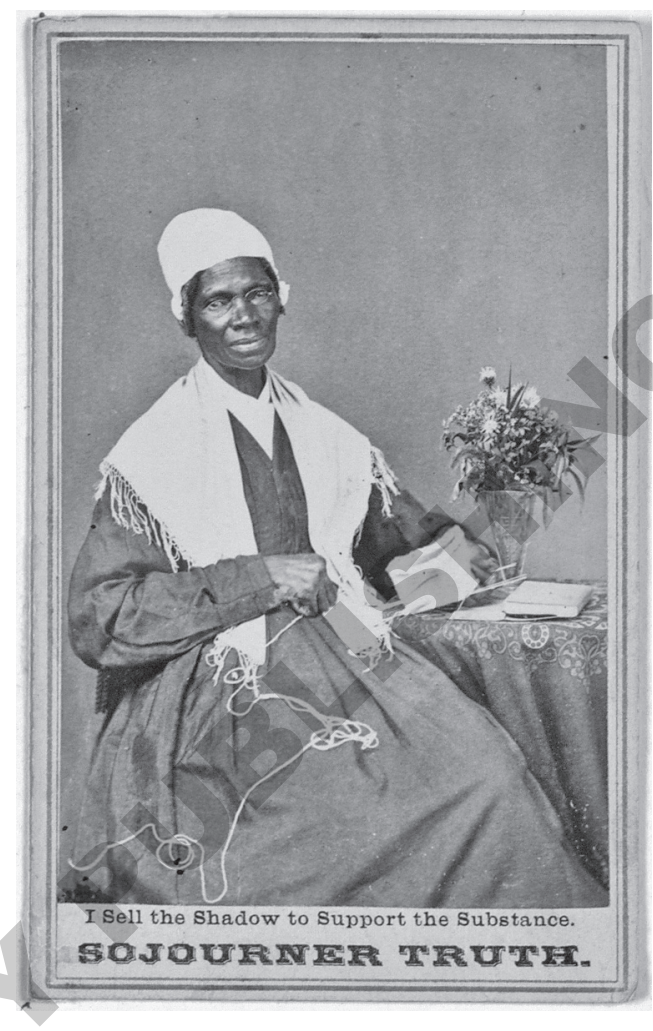

is variable for members of other cultures/classes/genders. The variability of Sojourner Truth's identities (a slave, a woman, a sojourner, a teller of truth) expresses itself in a plethora of names (Isabella van Wagener $=$ Sojourner Truth's name after the family who owned her; Isabella Baumfree = Sojourner Truth's possible birth name or that of her owners previous to the van Wageners; Sojourner Truth = her self-given name describing her self-determined identity as a religiously motivated abolitionist). ${ }^{8}$ Variable identities are unstable because they are subject to interpretation by members of the dominant culture, in whose view single aspects of identity may inflate to appear as the whole ("Sojourner Truth is a slave") and other aspects may vanish entirely ("Sojourner Truth is no woman").

Sojourner Truth's words, delivered in December 1851 at the Women's Convention in Akron, Ohio, would make no sense were it not for the understanding, fashioned during the Enlightenment and broadly accepted at the time of her speech one hundred years later, that a woman is implicitly white and middle class. Neither of these ideas, though, furnished Sojourner Truth with her 
principal point of attack and call for reconceptualization. Instead, she focused on the idea that may well have been, for her, the most profound paradox of all: the notion that as a worker, she could not be a woman because "woman" was understood to mean a soothing presence, a preserver of wealth, a beautiful soul, an angel in the house.

In the age of Enlightenment, "women" stopped working.

\section{EDUCATION}

Of course, even as "women" of the age stopped "working," women of the age continued to work. Lower-class women labored in a wide range of occupations, as spinners, seamstresses, washerwomen, milkmaids, cowherds, and domestic servants; paid work available to middle-class women was largely limited to three occupations-governess, actress, and writer. ${ }^{9}$ My focus in what follows will be on lower-class women writers, ${ }^{10}$ with only a brief coda on their middle-class colleagues, for two reasons. The simplest one is that we have many more written sources about women writers than about women in any other eighteenth-century profession. The more complex one is that the concepts with which this essay is most centrally concerned-ideas of work and education as they were applied to women in and beyond the age of Enlightenmentintersect most significantly in the writing by and about lower-class women. These documents thus provide us with ideal test cases for changing ideas about women and work during the epoch, specifically for the degree to which working women accepted or contested these ideas and in which context(s) they chose to do either.

For lower-class women poets of the age, work and education were central themes. Their representation as "unlettered" or "natural" geniuses in mid- to late eighteenth-century bourgeois aesthetics was predicated largely on their assumed ignorance of the aesthetic and philosophical background or poetic rules. ${ }^{11}$ Only the lower-class poet's lack of formal education could guarantee the naturalness and authenticity of her poetic output. "Elizabeth Bentley had no education; she read only by accident; but from the moment she did read, she felt in herself a power of imitation, and a faculty of combining imagery, together with a facility of poetical expression." 12 To her patron, the Scottish dairywoman Janet Little "betrays no one indication that I could discover of ever having opened a book or tagged a rhyme." 13 The Scottish domestic servant Christian Milne appears as a poet writing "without external aid from birth or education" who could not be judged by the standards applied to middle-class poets: "Let no stern critic . . . / talk of rules, when rules are all unknown" 
(emphasis in the original). ${ }^{14}$ The English cottager Ann Candler's utter lack of schooling showed "that her Poems are more the spontaneous productions of genius than the work of memory or education." ${ }^{15}$ And the work of the English domestic servant Mary Leapor was presented to readers "as a convincing Proof of the common Aphorism, Poeta nascitur, non fit" (a poet is born, not made). ${ }^{16}$

This "born" genius, then, writes spontaneously rather than painstakingly, aided not by book learning but by an astonishing "natural" ability to recall snippets of erudition that have haphazardly ("innocently") come her way. Several poets of the age were famous for their extraordinary abilities to recall text passages verbatim; the Scottish alehouse keeper Isobel Pagan, for example, although illiterate, could supposedly recite the entire Bible, word for word, from memory. In such depictions of the poet's mnemonic powers, her presentation as an unlettered genius clearly intersects with her characterization as a poor rural worker, for it is this unusual memory that enables the poet to write despite the constant interruptions that are part and parcel of her life. The image of the poet from the laboring classes, in other words, hinges centrally on both her complete lack of education and the fact that she continued to work physically. Milne composed her poetry while employed at physical labor throughout the week and remembered it all, verbatim, until she finally had a chance to write down her compositions on Sunday evenings. As Milne described the creative process,

Though the profits of my little book and the patronage of the worthiest people have been very sweet to me; yet those blessings have been much embittered by the ridicule and contempt with which I have been treated, by those among whom I am obliged to live, because I have been so idle as to write rhymes. But those respectable ladies and gentlemen whose names I have mentioned can witness that I have not been the more idle on that account; for I have composed my poems, such as they are, when I was most busily employed about my washing, baking, or when rocking the cradle with my foot, the ink-stand in one hand, the pen in the other, and the paper on my knee, with my children about me. When busy at work, I laid the paper and ink-stand beside me, and wrote the stanza as it came into my mind, and then to my work again. ${ }^{17}$

In Milne's narrative, the discourse of the humble laborer and that of the natural genius inform each other: on the surface, the statement is designed to protect the poet from accusations of "idleness" (by which is meant both the process of writing, which does not, in this narrative, count as real work, and 
the neglect of her household and wifely duties due to her writing). Her selfdefense against this accusation, her failure to describe her creative occupation as work and therefore respectable, indicates agreement with her accusers as to where her real duties lay and indirectly defines her as a peasant and housewife, rather than a poet. But the self-definition as a poet, and a "natural" poet at that, subtly injects itself into the narrative in her description of her writing as unconscious: poetic creation takes place at moments when she is "most busily employed," surrounded by either the wash or the children, at moments when her mind is clearly on other things. Milne's evocation of the unconscious creative process is strongly reminiscent of descriptions of the same process by the washerwoman Mary Collier, the first known eighteenth-century woman peasant poet, who conceived her verse "as on my Bed I lay, / Eas'd from the tiresome Labours of the Day": in a state between waking and sleep, during "moments of meditation that border on dream-work." 18

As these examples readily show, the aesthetic theory of the uneducated genius, originally advanced in the theoretical work of middle-class men, often turned into coercive practice in the poetic or autobiographical work of lowerclass women. Given that middle-class aesthetic theorists were very often also the patrons under whose protection lower-class authors wrote and published, this is hardly surprising. One of the more eloquent examples of the coerciveness of the natural genius idea is the case of Anna Louisa Karsch and her patrons. Karsch, a German cowherd without formal schooling, began her literary career as a local celebrity who entertained guests at village festivities, marriages, and funerals with impromptu poetry performances. Two months after she was discovered by the Baron von Kottwitz, who spirited her away to Berlin in his coach, Johann Georg Sulzer, one of the century's most important aesthetic theorists, wrote to his friend Johann Jakob Bodmer:

Here in Berlin, there has been an extraordinary apparition in circles of taste: a poetess formed by Nature alone, who, taught only by the muses, promises great things. . . . it is nothing to her to produce the finest thoughts on every subject and express them in excellent verse. I doubt very much that anyone has ever had language and rhyme as much in his power as this woman. She sits down in a large social gathering and amidst the chatter of twelve or more persons writes songs and odes of which no poet would need to be ashamed. ${ }^{19}$

Sulzer, who later claimed in his foreword to her poems that "poets are not formed through erudition and rules, but receive their calling and capacity from 
Nature alone," ${ }^{20}$ cited as evidence Karsch's unconsciousness when writing, her spontaneity and speed, her utter lack of formal education, and therefore her guaranteed lack of contact with poetic rules. ${ }^{21}$ His assessment of Karsch corresponds closely to his remarks in theoretical writings on the subjects of poetic inspiration, originality of invention, and poetic genius. ${ }^{22}$ Just as Sulzer, in his aesthetic works, views genius as a gift of nature, unattainable through training or education and closely linked with "physical circumstances," 23 so in his foreword to her poems he takes Karsch's biography as proof of the authenticity of her genius:

How indubitably our poetess has received her calling from Nature alone is evinced most clearly from all circumstances of her life. For in this life we find nothing, aside from natural inclination, that could possibly have instigated, artificially, her urge to write poetry, not a single circumstance that could lead us to surmise that erudite rules, in her case, take the place of genius. ${ }^{24}$

Karsch's literary career, in other words, centrally depended on her continued ability to embody bourgeois theories of "natural" poetic genius. Indications are that she was quite aware of this and did what she could to conform to this image by frequently emphasizing her humble origins and lack of formal education and by minimizing her exposure to reading whenever she could. "Art has no part of it," she claimed of her own writing, "and reading has only here and there added a touch." ${ }^{25}$ After first hearing of Edward Young's theory of natural genius, she professed herself a dedicated follower of his aesthetic and defined herself on his terms. ${ }^{26}$ The story of her early and insatiable desire to read and write that is a staple in the life stories of many of the century's peasant poets appears in her biography as well, complete with a touching account of strenuous parental opposition to her reading and writing. ${ }^{27}$ If Sulzer views the original impetus for her urge to write poetry as rooted in "Nature," Karsch makes an effort to place it as close to "Nature" as possible: according to her autobiographical letters, her love of poetry was first awakened by a young herdsman who read literature out loud to a circle of breathlessly listening peasant children. ${ }^{28}$ In letters to her patron Johann Wilhelm Ludwig Gleim, she frequently invokes the natural genius theory and self-applies it by emphasizing, as the primary traits of her writing, her speed and spontaneity, the tremendous memory for which she was already famous in the context of her impromptu performances, and the compulsion she felt to write poetry: her claim, in one of her last letters, that she wrote poetry in her sleep ${ }^{29}$ directly echoes the mandate 
of unconscious poetic production issued in aesthetic treatises. Her letters to Gleim and others often contain impromptu verse passages, and she countered Gleim's objections to her rhymed letters and his requests for proper prose epistles with apologies that are themselves, cheekily enough, written in verse:

Prose letters should I write, you say,

But can I, with my wayward thoughts?

Dear friend, your quarrel's not with me,

My habit brings all pains to nought,

Habit, this force of Nature strong

Compels me to relentless verse

And it's in verse that $\mathrm{I}$, in my last song

Will greet you even from my hearse. ${ }^{30}$

In this depiction of herself as "compelled to verse," as literally unable not to write, she skillfully evokes the aesthetic discourse of the poet as medium, helpless in the grip of the muse. Paradoxically, Karsch, who insisted that her letters were private documents and repeatedly refused to have them published, thus thwarted Gleim's attempts to make her letters appear more "private" and autobiographical (with an eye to potential publication) by deleting the rhymed interludes that might make the letters appear more "literary."

If the phenomenon of Anna Louisa Karsch was instrumentalized, at least initially, as the exemplification of natural genius theories, this image of her did not result in either poetic or financial autonomy for the actual poet. Although her first volume of poems was an unprecedented success, earning her the record honorarium of two thousand talers, she had no control over the capital, which was invested on her behalf by her patrons, Gleim and Sulzer, who acted as her legal guardians. When Karsch died in 1791, she left her children 3,600 thalers, but during her lifetime, she meagerly subsisted on the interest of this investment and depended on the patronage of various supporters for her survival and the education of her children. As in the cases of other peasant poets, this financial dependence had poetic consequences because it defined the reasons for publishing her work as not literary but financial: the goal of the edition, as stated by Sulzer in the foreword, was to "rescue [Karsch] from the direst poverty." 31 Karsch herself, taking her cue from him, often defined her writing as occasional poetry written exclusively for financial gain. In letters to Gleim, she repeatedly tried to influence the manner in which her patrons provided for her financially; her patrons, conversely, considered her financially unreliable and wasteful and for this reason controlled the capital 


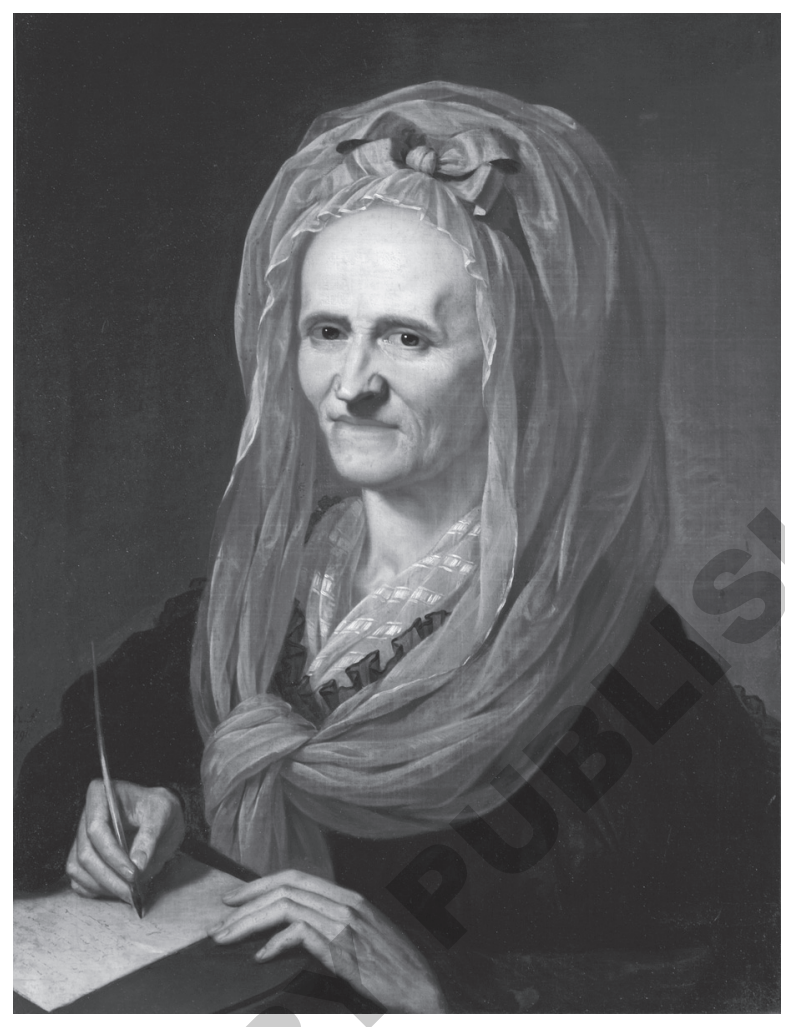

FIGURE 6.3: Portait of Anna Louisa Karsch, painted by Karl Christian Kehrer (1791). Oil on canvas. Courtesy of the Gleim-Haus Halberstadt.

all the more tightly. On the one hand, then, Karsch's patrons characterized their charge as an exemplification of natural genius and employed a rhetoric in which she appears as deserving of literary patronage; on the other hand, via their firm control over Karsch's finances, they defined that patronage as charity to the pauper.

\section{WORK AS A POETIC THEME}

I assure you that there are moments when Art almost attains to the dignity of manual labour.

-Oscar Wilde 32

Poetic representations of physical labor constitute a tradition that most obviously contravenes the pastoral, ousting the Arcadian shepherd from the text to 
make room for the laboring peasant. ${ }^{33}$ In contrast to the rather overdetermined pastoral tradition, these poems are characterized by a marked absence of literary context. Unlike the pastoral, they portray physical labor. Unlike the georgic, they do not present a positive or heroic view of labor. ${ }^{34}$ Unlike the nineteenth-century tradition of workers' literature, these earlier poems, while they depict the living and working conditions of the lower classes in the harshest possible terms, do not draw political or social conclusions; they cannot be considered "protest" literature in a sense that would align them with the proletarian tradition.

The two poems I discuss in this section treat physical labor or rural life in a way that can be considered neither "literary" (if literary implies fictional as opposed to factual) nor "personal" (if personal implies private as opposed to social or political). To be sure, Mary Collier's “The Woman's Labour” and Anna Louisa Karsch's "Schlesisches Bauerngespräch" ("Silesian Peasant Talk") use a literary form (meter and verse) and place themselves in a literary tradition; Collier's “Woman's Labour” is ostentatiously a response to another poem, Stephen Duck's “The Thresher's Labour.” Yet both document experiences that transcend "fiction" in three major ways: through their depiction of rural labor or working/living conditions that cannot be contained in either the pastoral or the georgic traditions; through their refusal to limit themselves to the "subjective" that has its place in "fiction" and can comfortably be contrasted with "objective fact"; and, finally, through their clear positing of the individual not as separate from or opposed to society but as its symbol and representative.

Collier's poem “The Woman's Labour” (1739), written in response to Duck's "The Thresher's Labour" $(1730,1736),{ }^{35}$ is the first published documentation of female rural labor by a woman laborer, provoked in part by Duck's depiction of female field hands sitting idly by, busily employing their tongues rather than their hands, while the men break their backs in the field. Collier's objective, then, is not merely the depiction of women's work, but its depiction as unnoticed and scorned (by men in general and Duck in particular). In the opening lines of the poem, Collier draws a clear distinction between herself and Duck: whereas Duck, formerly a laborer himself, has now ascended to the status of "Immortal Bard" and "Fav'rite of the Nine," not to mention favorite of the queen, who granted him her patronage, Collier "ever was, and's still a Slave," her life "always spent in Drudgery." ${ }^{36}$ Hers is a response written by a laborer during her rare minutes of leisure between the endless rounds of physical work she describes in the poem, a response addressed to someone for whom physical labor is, at most, a remembered experience. Implicit in this initial drawing of 
lines is Collier's distrust of Duck's selective remembrance, even her suspicion that he may have deliberately falsified the facts to embroider his fiction:

on our abject State you throw your Scorn,

And Women wrong, your Verses to adorn. ${ }^{37}$

Duck's concern, Collier asserts, is clearly no longer with work (its accurate representation as experienced reality) but with his verse (its embellishment for the benefit of his bourgeois and aristocratic readers). Her poetic reply therefore tries to eradicate this discrepancy between fact and fiction, and it is this aspect of Collier's poem, her dissociation of her own work from Duck's, that makes it possible to read her poem as a self-conscious documentary of work rather than a "poem" in the literary sense.

In what may well be the first description of the female double shift as full-time worker and housewife/mother, ${ }^{38}$ Collier documents a series of tasks performed by women in the fields, washhouse, and scullery and, finally, in their own homes. Emphasized throughout her elaborate depiction of haymaking, raking, plowing, reaping, gleaning, charring, washing, brass and pewter cleaning, beer brewing, cooking, bed making, swine feeding, and child and husband tending are the length and frenzy of a woman's workday and general work conditions (extremes of heat and cold), the physical injuries women undergo in the performance of labor (raw and bleeding hands), and the exploitation of women by upper-class men who underpay them and lower-class men who profit from but underappreciate their work. Repeatedly, a man's work conditions are explicitly contrasted with a woman's: the men, coming home from the fields, are finished for the day, waiting to be fed and go to sleep, whereas women returning from the fields

find our Work but just begun;

So many Things for our Attendance call,

Had we ten Hands, we could employ them all. ${ }^{39}$

Charwomen regularly rise at midnight to do the lady's washing,

While you on easy Beds may lie and sleep,

Till Light does thro' your Chamber-windows peep..$^{40}$

Collier's repeated examples of women's work performed while the men are asleep is, of course, a direct refutation of Duck's accusation of female idleness; her summing up 
Our Toil and Labour's daily so extreme,

That we have hardly ever Time to dream (emphasis in the original $)^{41}$

again emphasizes to what extent the longer workday of women encroaches on their sleep and simultaneously takes up Duck's statement that work follows the laborer into his dreams. While Collier's description of field labor is comparatively brief, she elaborates on those areas of work that are specific to women, such as washing: in this, as well, she deliberately pits the woman's work against the man's ("So many Hardships daily we go through, / I boldly say, the like you never knew" [emphasis in the original $]^{42}$ ). A washerwoman's day begins in the middle of the night, when

O'ercome with Sleep; we standing at the Door

Oppress'd with Cold, and often call in vain,

E're to our Work we can Admittance gain. ${ }^{43}$

The arduous work of scrubbing, washing, laying out, and bleaching, and the treatment of sensitive materials like ruffles, lace, and fringes, are interrupted only by the mistress's admonishments to save on soap and firewood. This work goes on

Until with Heat and Work, 'tis often known,

Not only Sweat, but Blood runs trickling down

Our Wrists and Fingers; still our Work demands

The constant Action of our lab'ring Hands. ${ }^{44}$

Collier's poem ends on a grim note: the laborer is paid off with "Six-pence or Eight-pence"; the future holds nothing for the laborer but "Old Age and Poverty" (emphasis in the original) and continuous exploitation by "sordid Owners [who] always reap the Gains." ${ }^{45}$ Her concluding image of women laborers as the daughters of Danaus, with which she answers Duck's comparison of the male field hand with Sisyphus, ${ }^{46}$ characterizes the poem's author simultaneously as a poet and as a washerwoman. A literary allusion to Greek mythology in a poem about labor by a laborer who, in its opening lines, describes herself as completely uneducated could be considered a rather incongruous motif. And yet it is paradoxically this highly literary image of the eternal washerwomen, endlessly employed in filling the bottomless tub, that most succinctly reiterates Collier's description of women's labor as never-ending and thankless.

Collier's poem, ostentatiously concerned with gender as well as class, answers Duck's work (and foreshadows Sojourner Truth's insight) in another way 
as well. Whereas Duck, in his elaborate description of women as uselessly prattling gossips, can be said to accentuate traditional views of femininity, Collier's response obscures the femininity of female workers who, covered with soot, dirt, and filth at the end of their workday, can no longer be recognized as women:

Colour'd with Dirt and Filth we now appear;

Your threshing sooty Peas will not come near.

All the Perfections Woman once could boast,

Are quite obscur'd, and altogether lost. (emphasis in the original) ${ }^{47}$

Collier's elimination of femininity from the image of rural womanhood is reiterated in the comments of bourgeois observers, who frequently bemoaned the fact that many rural women looked like men and lacked the feminine qualities of virtue and ladylike reticence as they walked behind the plough. An observer of women's field labor in 1794 found it positively

painful . . . to behold the beautiful servant maids of this country toiling in the severe labours of the field. They drive the harrows, or the ploughs, when they are drawn by three or four horses; nay, it is not uncommon to see, sweating at the dung-cart, a girl, whose elegant features, and delicate, nicely-proportioned limbs, seemingly but ill accord with such rough employment. ${ }^{48}$

How laboring women appear to the male observer is also a substantial part of, indeed furnished the provocation for, Collier's poem, where the elimination of femininity serves a distinct purpose: it negates the male view of women (either as beautiful and delicate or as useless, lazy, and gossipy) and identifies work as the defining aspect of a woman's existence. Woman, in her description, is no longer recognizable as a woman but merely as a worker. Nevertheless, and this seems to be Collier's implicit conclusion, the view of this worker as a woman persists, and must persist, for it is this distinction that makes it possible to pay her even less for her labor than the already insufficient male wage and to saddle her with a workload that is described as double that of the male worker. Collier's poem is thus, as Landry has read it, a protofeminist work; ${ }^{49}$ it is class identified in its clear indictment of the exploitation of the rural laborer through upper-class employers, but it simultaneously furnishes one of the earliest examples of a gendered critique of the exploitation of lower-class women not only by the upper classes but also by men of their own class. 


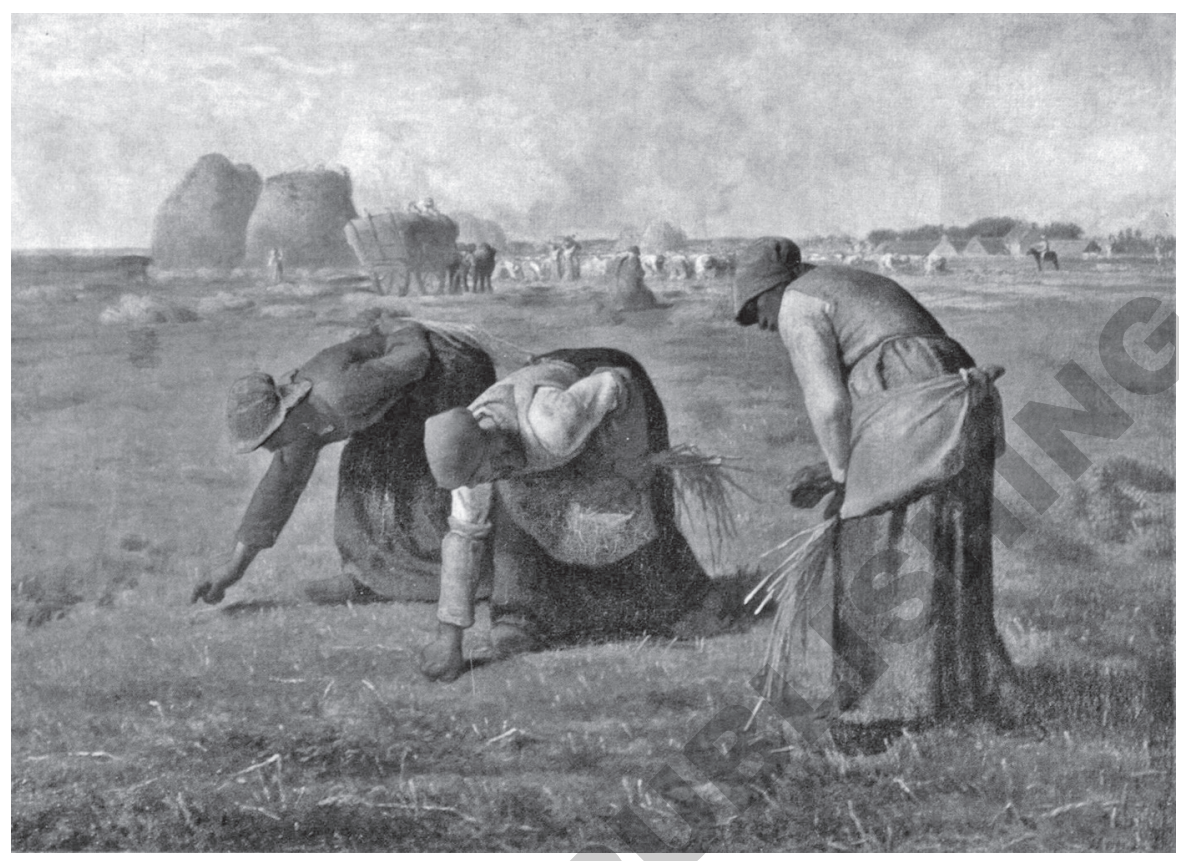

FIGURE 6.4: Peasant women working in the fields. Jean-François Millet (1814-75), Des glaneuses (The Gleaners) (1857). Musée d'Orsay, Paris.

Anna Louisa Karsch’s “Schlesisches Bauerngespräch zwischen Vetter Hanß und Muhm Ohrten, gehalten zu R . . bei Großglogau im November 1758" (Silesian peasant talk between Cousin Hans and Aunt Ohrte, which took place in R . . near Großglogau in November 1758$)^{50}$ makes us privy to a discussion between two peasants on the impact of the Seven Years' War on the rural population. The conversation progresses from complaints about heavy taxation and the mistreatment of peasants in times of war to the praise of rural life in peacetime, finally ending in a panegyric on Frederick the Great. The poem deliberately mixes public with private spheres (in its intertwining of larger political and social concerns and personal matters in the conversation) and literary concerns with rural reality. Written in the Silesian dialect, it is one of the earliest dialect poems in the German language and clearly attempts to emulate real-life conversation in other ways as well, particularly in the unmotivated changes of subject and the interspersing of seemingly irrelevant news, such as Cousin Lehne's preparations for her brother's visit. In addition, the exact designation of time and place in the poem's title establishes a claim to realism by 
anchoring the conversation in a specific historical context: the reader's position as a consumer of didactic literature is obscured by the intimated role of someone listening in on a private conversation. At the same time, the employment of alexandrine meter ${ }^{51}$ throughout the poem places it into a literary tradition; Ernst Josef Krzywon, for instance, has read the poem as an example of the political poetry of the German baroque (Bauernklage) and linked Karsch's usage of literary form to both Martin Opitz and Johann Christoph Gottsched. ${ }^{52}$ While the deliberate (mis)use of the "heroic" alexandrine meter would seem to hint at a subversive evocation of literary traditions, both the panegyric on the king and the portrayal of peasant life in peacetime evoke other literary traditions, including pastoral and georgic forms, without a trace of irony. Rural reality, as it appears in Hanß's description, is characterized by health, piety, hard work, a loving family life, and a delight in plain rustic fare, all of which are elaborately contrasted with the city dweller's corruption, hypocrisy, lavish eating habits, and frequent illnesses.

Although labor supposedly dominates this idyllic life, only four lines out of sixty-two in his speech even mention physical work; ${ }^{53}$ the rest of Hanß's report is given over to philosophical and religious ruminations about the virtues and pleasures of country life. In this respect, one might be inclined to read this poem as indebted to the traditional pastoral and/or georgic, and not, as Helene M. Kastinger-Riley has done, as a "mirror of the true rural milieu" ${ }^{54}$ or as based in any way on Karsch's "vivid personal experience." 55 But if Karsch, rather than describing work as she knew it, fell into the pastoral trap, she simultaneously negates a literary tradition: in claiming the pastoral for the peasant, she ostentatiously defies the bourgeois depiction of the literary peasant as coarse, unrefined, and ridiculous, the comic character of rural literature. ${ }^{56}$ She does this not only by usurping the Arcadian shepherd's space for the peasant but also by hinting at an—albeit imagined—reality. For Hanß's initial complaints about the heavy taxation during wartime-peasants in times of war paid between 33 and 45 percent of their total income in taxes directly to the armies ${ }^{57}$ - are trumped by Ohrte's account of the unimaginable suffering visited on the peasant under enemy occupation. Ohrte's fiction within a fiction, her act of imagining potential disasters destroying the pastoral idyll that poses as "fact" within the poem, is paradoxically the passage that comes closest to evoking rural reality: the peasant's farm is burned down, his seeds destroyed, his grain, livestock, and household goods stolen.

This attempt to represent real suffering disintegrates at the point where the suffering is perceived as so extreme that it can no longer be contained in the 
pastoral or georgic form that provides the poem's frame. Whereas Karsch manages to convey highly affecting images of the peasant being beaten by troops and his barn and stables being emptied, the experience of rape in wartime is rather mincingly hinted at:

And many a man has had to witness, stand amazed

As soldiers treat his wife in most improper ways

One does not like to speak of it. But really, it's a fright

To hear of things the Russians do to young women at night.

One listens to these things, it is no laughing matter,

And your wife, Hanß, is pretty, the village has none better,

Cossacks would gladly take her, their hours to while away,

And you'd be spitting mad, and there'd be hell to pay. ${ }^{5}$

At this point, Karsch's attempt to convey rural reality in the pastoral form breaks down, form proving woefully inadequate to content. This painful inappropriateness is expressed in euphemisms that demote a crime to "improper" behavior, helplessness and despair to a childish tantrum ("spitting mad"; in the original: "Du argertest Dich närsch"), and the destruction of lives to "no laughing matter." In a literary world that is engaged in an aestheticization of rural reality, as Hanß is in the elaborate description of his workday, such experiences are beyond the words available to the genre.

Karsch's "Schlesisches Bauerngespräch" is a good test case for what happens when the pastoral meets rural reality in a text that is primarily concerned with the latter rather than the former. Her poem tries to adapt the traditional pastoral and georgic to a different purpose, one that is not, like a mock-pastoral would be, strictly literary. The didactic purpose of the poem is essentially conservative, as expressed in both Hanß's idyllicization of rural life and the elaborate apotheosis of the king. Nonetheless, Karsch attempts, as KastingerRiley has noted, to give the peasant his due: in contrast to bourgeois portrayals of the peasant as the klutzy comical character, peasants in this conversation appear as the backbone of rural society as well as of Frederick's war. ${ }^{59}$ Without question, Karsch portrays it that way; at the same time, it is difficult to overlook the aestheticization inherent even in this acknowledgment of the peasant's vital role: in a precise parallel to the denial of labor and the depiction of unworked-for rural bounty in the traditional pastoral, the peasant's forced contributions appear, in her poem, as voluntary offerings. Karsch's poem thus seems essentially torn. On the one hand, it aestheticizes rural life and glorifies the king with the help of traditional poetic forms (the pastoral and the 
georgic). On the other hand, its employment of dialect, the attempts to emulate real-life conversation in the frequent jumps, non sequiturs, unmotivated subject changes, and the relation of seemingly unimportant details seem to express a social purpose, namely, the realistic portrayal of lower-class concerns. Where rural reality threatens the pastoral idyll, as it does in the rape story, the pastoral is quickly reasserted in the refusal to engage reality ("One does not like to speak of it") and in the conformist conclusion that peasants should recognize that, compared to such horrors, their current hard lives are a veritable bed of roses:

That pittance of a tax is all you suffer now

And trifle that it is, you whine and make a row. ${ }^{60}$

Despite her radically different perspective, Karsch's poem can be read from within the tradition of women's labor poems. Like Collier, she attempts to describe rural reality from within a literary form. Whereas she rather downplays the labor theme, she emphasizes exploitation in her assessment of the consequences of war for the rural population. Both Collier and Karsch express their understanding of exploitation as the essence of lower-class experience, represented in Collier's poem in the class-encompassing "we" and in Karsch's in the exchange between two different people with two distinct perspectives (Hanß complains, Ohrte appeases). Whereas Collier's work demonstrates both class consciousness and class solidarity in the depiction of the servants' exploitation, Karsch tries to find a way to map the pastoral sense of contentment onto the rural reality she describes, accordingly downplaying and negating the fact of exploitation that Hanß, at the outset of the poem, protests so vigorously, and turning this protest into praise of the king in the peasant's mouth.

\section{POVERTY IN POETRY: WORK AND EDUCATION REVISITED}

In one of her letters to her patron Bridget Freemantle, Mary Leapor imagines herself a successful poet:

If our scheme succeeds, I intend to shew my public spirit: . . . I shall erect a few Almshouses; and have some thoughts of founding a hospital for indigent or distracted poets. I presume this will take up as much of my superfluous wealth as I can spare from the extravagance of a gay retinue and splendid equipage, in which I intend to abound. Amidst all this, I shall not be ingrateful, though perhaps somewhat haughty. Yet my 
chariot or landau shall ever be at your service, and ready to convey you to my country-seat, or to my house in Hanover-square. ${ }^{61}$

What Leapor lampoons here is the prejudice against which the common discourse of the humble cottager, content in her station, was intended to serve as defense: the fear, obsessively expressed in the writing of bourgeois patrons, ${ }^{62}$ that elevating peasants above their "stations" would invariably result in their transformation into idle, haughty, luxury-loving, and ungrateful wretches. Leapor's charitable intentions of erecting "almshouses" and hospitals for "indigent or distracted poets" are also an unmistakable comment on the nature of patronage, here perceived precisely in the way in which Gleim and Sulzer practiced it on Karsch: as charity to the pauper rather than patronage of the poet.

And yet Leapor's satire is an uncomfortable one, her dream of "superfluous wealth" all too obviously implying its reverse, which is of course the main reason why the peasant poet requires patronage (the secondary reason being the opportunity to write and publish). In the work of lower-class poets, poverty is a regularly recurring theme. Christian Milne's "The Wounded Soldier" describes a starving family in heartrending terms; Ann Candler's "Reflections on My Own Situation” provides a glimpse of the author as a pauper living on meager alms "with the dregs of human kind." ${ }^{63}$ An untitled impromptu poem by Karsch, inserted seamlessly into a letter to Gleim, depicts similar circumstances:

oh dearest Gleim see fathers hurry, in vain to work for just a little bread, meanwhile beset by cold and hunger's dread, the children cry, redoubling his worry, they cry like dogs deprived of mother's breast, their mothers roam the streets full of despair, the children are abandoned everywhere, like little ravens flung out of the nest, they hope for bread from morning until night, and many sick and poor lie on the straw, not even granted water in their plight, whereas the rich do shove into their maw, the most delicious foods till they are ill, I see this sadly, much against my will, my spirit bids me forget nevermore, that I myself was hungry, cold and poor. ${ }^{64}$

The question of what could lift the poet out of poverty, a term that in poems may indicate physical penury or intellectual deprivation, is often answered by pointing at the lower-class poet's forbidden fruit: education. Numerous poets who, in poems and autobiographical writing produced for public consumption (such as forewords to their editions), strategically adopted the self-image of 
the unlettered poet, expressed, in personal letters, profound regret at having been denied a formal education. Karsch, for example, often lamented the fact that her mother removed her from her uncle's tutelage at a crucial stage in her learning: "I am still upset that my mother did not leave me with my old uncle; he would have taught me Latin and I could now read Flacchus and Virgil." 65 The same indictment is levied in her poem "Ann meine Mutter in jene Wellt geschrieben den dritten Juny 1785" (To my mother, written to her in the other world on the third of June 1785), but in this poem, she sarcastically turns blame into gratitude for the ignorance in which she was kept:

But upon further contemplation

I am quite certain that your daughter

Would not be seen as a sensation

If you had more than German taught her

For if you had, then folks would say

That I pilfered from him, or him

Who wrote poetry in the ancient days

That must be why it was your whim

To save me from Latin and erudition,

Accept, dear Mother, my contrition,

Your nagging thus my thanks has earned

'Tis my good fortune I'm unlearned. ${ }^{66}$

Karsch's ironic self-image as "unlearned" implies an obvious conundrum: in her letters, Karsch regretted her limited education, particularly her ignorance of foreign languages, to the end of her days; simultaneously, she was well aware that it was this ignorance that enabled her entire career as a "natural" poet. For lower-class ("uneducated") women writers, education constituted an irresolvable paradox. ${ }^{67}$ On the one hand, it stood for the (for them, tabooed) erudition of the male, middle-class writer. On the other hand, it alone distinguished the "author" from the hack, the career writer from the literary nineday wonder.

Work as a subject in these poems is beset by a similar ambiguity, simultaneously implying physical labor performed under threat of poverty ("work") and the more genteel exertions of the poet at her escritoire ("the work"). The work (at times also known as "poetic idleness"; see Christian Milne) is, in fact, what enables the poet to stop working. In Karsch's “Meine Zufriedenheit” (My contentment), poverty is a personal experience shudderingly remembered but now thankfully in the past: 
My fingers now no longer tear the flax,

I, now so used to wine, am never parched

With thirst, laboring under the distaff's arch,

And never does the sun melt me like wax.

When Sirius's flame in vale and glade

Burns up the thresher, tires the walking boy,

Then I sit bless'd with bounty and with joy,

In plenty do I rest, and in the shade.

O friend! and when the spinner's hand

Laboriously tears and rents the cotton wool,

Then I now play my undemanding role

Which often wins me praise throughout the land!68

At its most obvious, Karsch describes poetry as a ticket out of poverty, but there is more here. There is, in fact, an implication that poverty contextualizes poetry in a way that negates bourgeois claims of the transcendence and nobility of literature. Poetry written from within poverty, past or present, accentuated or submerged, can make no such claim. The business of poetry is rather prosaically downgraded to easy (rather than arduous) labor, performed in the shade rather than under the scorching sun. This depiction of writing as easy work is predicated on the understanding of writing as work, a simultaneous violation of four mandates: the pastoral tradition that excludes labor from literary representation, the new bourgeois understanding of bourgeois literature as transcendent and written for posterity, the interpretation of lower-class poetic occupation as "idleness," and the aesthetic/critical view of the peasant poet as spontaneously inspired and therefore, by implication, incapable of (poetic) work (such as editing or rewriting). Peasant poets' literary aspirations, at least as presented in their poetry, are often neither prompted by a sense of themselves as "natural geniuses" nor inspired by bourgeois-style dreams of posthumous fame but are instead simply aroused by a desire for an improvement in their working conditions.

While in laborious toil I spent my hours, Employ'd to cultivate the springing flowers:

Happy, I cry'd, are those, who leisure find

With care, like this, to cultivate their mind. ${ }^{69}$ 
In this poem, Leapor views intellectual labor "like this," in other words: as comparable to physical work rather than as its antithesis, as indeed Karsch did in her poem on contentment. The difference, as both Karsch and Leapor knew, lay in the kind of work and in the circumstances under which it was performed, not in a contrast between (physical) work and (poetic) idleness. Unlike the cultivation of a garden, the cultivation of a mind may be performed in the shade; it may, as Leapor states, sport the appearance of "leisure." The poet thus employed may, as Karsch has said, seem to be merely "resting," but writing is nevertheless, in a marked deviation from the assumptions of bourgeois and pastoral discourses, recognized as work.

\section{CODA: WORK AND “THE WORK”}

It is perhaps this aspect that marks the most extreme difference between the writing of lower-class women and that of middle-class women of the Enlightenment. Middle-class women writers regularly denied that their work was "work," in more or less the same manner in which lower-class women writers strategically self-applied the natural genius theory. Luise Adelgunde Gottsched, for example, one of the century's most highly educated women and most prolific writers, defined much of her work as legwork in support of her husband's literary and bibliographic projects. ${ }^{70}$ Dorothea Schlegel, who published her novel Florentin anonymously (it was, in fact, widely believed to have been written by her husband), insisted, once her authorship was known, that she regarded the book not as an artistic undertaking but as a financial one: its sole purpose, she claimed, was to round out the family income so that her husband, thus somewhat relieved of the necessity to provide for the family, could concentrate on his art. ${ }^{71}$

These two examples, to which many others could be added, ${ }^{72}$ show that both education and work assumed highly ambivalent meanings in women's writing that moreover clearly relate to the class context in which the terms were used. Lack of education was often perceived, by lower-class writers, as an obstacle to their advancement into the realm of the (middle-class) writer, which - to them-also represented the realm in which it was no longer necessary to work (physically) for one's survival. Too much education, on the other hand, could ruin both the career of the "natural genius" and the reputation of the bourgeois housewife. Thus, both groups regularly misrepresented their work as unlettered, unerudite, and unintellectual. "Work," as well, assumes a class-specific ambivalence when used by women writers. If lower-class women 
classed their oeuvre as work, albeit easy work by comparison to physical labor, middle-class women were often extremely careful to cast their literary activity as purely supportive of their husbands' more important literary projects. Their work, in other words, is redefined as housework; the author becomes the literary equivalent of Schiller's housewife, who collects, preserves, and "adds" but does not actually "work."

For the past two hundred years, readers of women's literature have had to contend with these ideas. They are perpetuated, for example, in the seemingly irreparable rift between male writers (commonly assumed to be dedicated to their art) and female writers (commonly assumed to be in it for the money). To contest this and other assumptions about men's versus women's literature, as feminist criticism has done since at least the 1970s, leads straight into yet another dilemma: the question of whether women's writing can be fairly considered within a tradition of philosophical and literary movements and cultural contexts shaped by men or whether it should be read "on its own terms." 73 Readers of women's literature are thus faced with an unappetizing alternative, that of either ghettoizing women's literature or applying to it aesthetic and philosophical criteria that social and cultural histories of literature have shown to be largely or entirely inapplicable. Either way, reading women's writing still involves considering questions that women writers of the Enlightenment indirectly asked of their readers two hundred years ago. Among these, we might find the following: Can the work's reception overcome its inception? Is literature that was so resolutely diminished, undercut, and belittled, by both its authors and its critics, eligible for a reception as Great Art, with all the unassailable certainties and claims to transcendence this implies? Can the aesthetic criteria of the past be rethought to a degree that would make such an understanding possible? Can work that has been disparaged as easy work, legwork, or housework ever become "the work"? 